\title{
Effects of fermentation with Lactobacillus rhamnosus GG on product quality and fatty acids of goat milk yogurt
}

\author{
Ru Jia, ${ }^{1}$ Han Chen, ${ }^{1}$ Hui Chen, and Wu Ding ${ }^{2}$ \\ College of Food Science and Engineering, Northwest A\&F University, Yangling Shaanxi 712100, China
}

\begin{abstract}
The effect of fermentation with Lactobacillus rhamnosus GG on the product quality of goat milk yogurt using traditional yogurt starter was studied through single-factor experiments and orthogonal experiments. The optimum fermentation condition was evaluated by the titratable acidity of goat milk yogurt, waterretaining capability, sensory score, and texture properties; the fatty acids of the fermented goat milk were determined by a gas chromatograph. Results indicate that high product quality of goat milk yogurt can be obtained and the content of short-chain and mediumchain fatty acids can be decreased significantly when amount of sugar added was $7 \%$, inoculation amount was $3 \%$, the ratio of 3 lactic acid bacteria-Lactobacillus delbrueckii ssp. bulgaricus, Streptococcus thermophilus, and L. rhamnosus GG - was 1:1:3, and fermentation temperature was $42^{\circ} \mathrm{C}$.
\end{abstract}

Key words: Lactobacillus rhamnosus GG, goat milk yogurt, product quality, fatty acid

\section{INTRODUCTION}

Goat milk is a healthy and nutritious food (Haenlein, 2004) and is recognized as the most similar in nutritive value to human milk. In addition, goat milk has been attributed certain therapeutic values in human nutrition (Park, 1994; Spuergin et al., 1997; Alférez et al., 2001; Barrionuevo et al., 2002; Zhao et al., 2014). However, the smell of goat milk has been described specifically as "goaty" and has resulted in consumers discarding goat milk products in the past (Haenlein, 2001). The specific smell of goat milk is related primarily to the composition of the fatty acids (Chilliard et al., 2003). The content of caproic $\left(\mathrm{C}_{6: 0}\right)$, caprylic $\left(\mathrm{C}_{8: 0}\right)$, and capric $\left(\mathrm{C}_{10: 0}\right)$ acids in goat milk are slightly higher than that of cow milk (Barber et al., 1997; Chilliard et al., 2000), and these acids compose $13.3 \%$ of the total

Received July 14, 2015.

Accepted September 9, 2015.

${ }^{1}$ These authors contributed equally to this work.

${ }^{2}$ Corresponding author: dingwu10142000@163.com fatty acids in goat milk (Soryal et al., 2003). During fermentation, goat milk will lose its "goaty" smell and the nutritive value of goat milk can increase (Slacacac et al., 2010). This mechanism of "goaty" smell removal through fermentation has not been clearly studied indepth.

As the public's interest in potential beneficial health effects of probiotics has increased, many products have been proposed as carrier foods for probiotics to improve the health and nutrition of people (Gilliland, 2003; Senaka Ranadheera et al., 2013). Goat milk yogurt is a fermented milk products (Merin, 2000) with the potential to carry probiotic bacteria (Hekmat and Reid, 2006; Settachaimongkon et al., 2014). To exert any beneficial health effect, the concentration of probiotics in a product must be over $10^{6} \mathrm{cfu} / \mathrm{mL}$ (Donkor et al., 2007). Most commercial probiotics incorporated in dairy products are strains belonging to the genera Lactobacillus and Bifidobacterium (Lourens-Hattingh and Viljoen, 2001). But the research on fermentation with probiotic strain such as Lactobacillus rhamnosus GG of goat milk yogurt is rare. The ability of L. rhamnosus GG to survive and colonize in the gastrointestinal tract has been shown for both adults and children (Goldin et al., 1992; Millar et al., 1993; Saxelin et al., 1993). It can adjust intestinal flora, prevent and cure diarrhea, eliminate toxins, and enhance immunity against dental caries (Linares et al., 2011).

In our study, goat milk yogurt was fermented with a mixture of L. rhamnosus GG and traditional yogurt starter cultures, Lactobacillus delbrueckii ssp. bulgaricus and Streptococcus thermophilus, through single-factor experiments and orthogonal experiments. The aim of this study was to investigate the effect on the product quality and fatty acids of goat milk yogurt through the fermentation, which can provide better process parameters and process flow for a new goat milk product.

\section{MATERIALS AND METHODS}

\section{Materials}

Fresh goat milk was obtained from the Xinong Saanen dairy goat seed farm in Yangling (Shaanxi Prov- 
ince, China). Yogurt starter cultures, S. thermophilus and L. delbrueckii ssp. bulgaricus, were provided by our laboratory. Lactobacillus rhamnosus GG was bought from the China Industrial Culture Collection Center (Beijing, China).

Fatty acid methyl esters standard material, used as a reagent, was produced by Supelco (Bellefonte, PA). Methanol, $n$-hexane, boron trifluoride-methanol solution (14\%), $0.55 \mathrm{M}$ potassium hydroxide methanol solution, pyrogallic acid methanol solution (10\%), chloroform, and saturated sodium chloride solution were also used as reagents.

\section{Preparation of the Starter}

Strains were activated first via sterilization of the skim milk at $105^{\circ} \mathrm{C}$, of which the solids concentration is $11 \%$ (wt/wt). The lyophilized powder of $S$. thermophilus, L. delbrueckii ssp. bulgaricus, and L. rhamnosus GG was activated in the skim milk and then stored at $4^{\circ} \mathrm{C}$.

Mother culture was prepared with sterilized skim milk that had $5 \%$ inoculation amount of the activated strains. The mother cultures of $S$. thermophilus and $L$. delbrueckii ssp. bulgaricus were incubated at $42^{\circ} \mathrm{C}$ and the mother culture of $L$. rhamnosus GG was incubated at $37^{\circ} \mathrm{C}$. They were then stored at $4^{\circ} \mathrm{C}$ until the curd was firm.

\section{Fermentation of Goat Milk Yogurt}

The raw goat milk was purified using a filter cloth. After adding sugar, goat milk was heated to $95^{\circ} \mathrm{C}$ for 5 min using pasteurization and cooled to $45^{\circ} \mathrm{C}$. Then the goat milk was inoculated with $S$. thermophilus, $L$. delbrueckii ssp. bulgaricus, and L. rhamnosus GG in different ratios, which were determined by the preliminary experiments; finally, goat milk was fermented at $4^{\circ} \mathrm{C}$.

\section{Determination of Titratable Acidity}

According to China National Standard GB 5413.342010, the titratable acidity of goat milk yogurt was determined with $0.1 \mathrm{M} \mathrm{NaOH}$ standard solution titration method (Lin et al., 2004), where $10 \mathrm{~g}$ of goat milk yogurt sample was added to $2 \mathrm{~mL}$ of phenolphthalein solution (1\% wt/vol in ethanol) and the mixture was titrated with standardized $0.1 \mathrm{M} \mathrm{NaOH}$ until the color changed to pink. The volume consumed by titration of $\mathrm{NaOH}$ standard solution was recorded and then the titratable acidity (degrees Thorner; ${ }^{\circ} \mathrm{T}$ ) of goat milk yogurt was calculated according to equation [1]:

$$
{ }^{\circ} \mathrm{T}=c \times v \times 100 /(m \times 0.1),
$$

where $c$ is the molarity of $\mathrm{NaOH}$ standard solution; $v$ is the volume consumed by titration of $\mathrm{NaOH}$ standard solution; and $m$ is the mass of the goat milk yogurt sample.

\section{Determination of Water-Retaining Capability}

Water-retaining capability was determined by the methodology proposed by Hassan et al. (1996). Samples of the goat milk yogurt (15-20 g) were centrifuged at $13,500 \times g$ for $30 \mathrm{~min}$ at $10^{\circ} \mathrm{C}$. The centrifuge tube was kept inverted for 10 min after decanting the clear supernatant, and then the sediment was weighed. The water-retaining capability was calculated according to the equation [2]:

Water-retaining capability $(\%)=[$ weight of sediment

$$
\text { (g)/weight of sample }(\mathrm{g})] \times 100 \% \text {. }
$$

\section{Analysis of the Quality and Structure of Goat Milk Yogurt}

The quality and structure of goat milk yogurt were analyzed by the Texture Analyzer (TA. XT2i/50, Stable Micro Systems Ltd., Godalming, UK). Samples of the goat milk yogurt were placed on the platform of the machine and then penetrated by a 35-mm-diameter A/ BE probe (Stable Micro Systems Ltd.). Samples were tested by a trigger force of $5 \times g$ at an acquisition rate of 200 points per second. The test parameters were set as follows: pretest speed $=1.0 \mathrm{~mm} / \mathrm{s}$; test speed $=$ $1.0 \mathrm{~mm} / \mathrm{s}$; post-test speed $=1.0 \mathrm{~mm} / \mathrm{s}$. The penetration distance was $30.0 \mathrm{~mm}$. Three replications were analyzed using separate repeat samples. The results were expressed as firmness, cohesiveness, and index of viscosity.

\section{Sensory Evaluation}

The sensory qualities of the goat milk yogurt were evaluated by 5 trained panelists ( 3 male, 2 female; 20 to $30 \mathrm{yr}$ old) using the quantitative response scales method (ISO 4121; ISO, 2003). The panelists were trained on flavor profiles, the sniffing technique, the use of scales, and the intensity-rating procedure in accordance with international standards (ISO 8586; ISO, 2012). The sensory training was carried out before sensory evaluation (Yang et al., 2015).

Samples of the goat milk yogurt, contained in screwcap glass bottles, were randomly marked with 3-digit numbers and presented in random order. Before tasting each sample, the panelists were required to rinse their mouth thoroughly with deionized water. Samples were 
scored in terms of whiteness (the score ranged from 0 to 20), aroma (the score ranged from 0 to 20), taste (the score ranged from 0 to 30 ), and shape (the score ranged from 0 to 30 ) according to the provided standards. Three replicates were measured using separate repeat samples.

\section{Extraction of Goat Milk Yogurt Fatty Acid}

For extraction of fat, $2.4 \mathrm{~mL}$ of fermented goat milk yogurt was put into a $30-\mathrm{mL}$ polypropylene centrifugal tube. Next, $1.6 \mathrm{~mL}$ of distilled water, $10 \mathrm{~mL}$ of methanol, and $5 \mathrm{~mL}$ of chloroform were added, blended, and shaken. Five milliliters of distilled water and chloroform were then added, oscillated (2 min), and centrifuged $\left(1,700 \times g, 10 \mathrm{~min}\right.$ at $\left.10^{\circ} \mathrm{C}\right)$. The chloroform solution in the bottom layer of the centrifugal tube was transferred into a conical flask and was evaporated until dry in a $65^{\circ} \mathrm{C}$ water bath.

Methyl esterification of fatty acid was done by adding $0.25 \mathrm{~mL}$ of pyrogallic acid methanol solution into fat concentrate, as mentioned above, and then evaporated until dry in a $65^{\circ} \mathrm{C}$ water bath. Subsequently, $2.5 \mathrm{~mL}$ of potassium hydroxide methanol solution was added into the concentrate and it was reflowed for 5 to $10 \mathrm{~min}$ in an $80 \pm 1^{\circ} \mathrm{C}$ water bath. The fluid was then reflowed for $15 \mathrm{~min}$ in an $80 \pm 1^{\circ} \mathrm{C}$ water bath again after adding $1.5 \mathrm{~mL}$ of boron trifluoride-methanol solution; then, the fluid was transferred into the centrifugal tube with $3 \mathrm{~mL}$ of saturated sodium chloride solution. Next, 2.5 $\mathrm{mL}$ of $\mathrm{N}$-hexane was added into the centrifugal tube and then centrifuged at $2,200 \times g$ for $10 \mathrm{~min}$ at $10^{\circ} \mathrm{C}$ after oscillation. The supernatant was measured after microfiltration by a gas chromatograph (Shimadzu GC2014C, Kyoto, Japan) with a DB-17 column (30 m, $0.25 \mathrm{~mm}$ i.d., Agilent, Santa Clara, CA). Temperatures of the inlet and flame-ionization detector were 260 and $280^{\circ} \mathrm{C}$, respectively. The oven temperature was kept at $100^{\circ} \mathrm{C}$ for $5 \mathrm{~min}$ and then raised to $240^{\circ} \mathrm{C}$ at a rate of $4^{\circ} \mathrm{C} / \mathrm{min}$, with a final isotherm of $15 \mathrm{~min}$. The pressures of the flame-ionization detector air, hydrogen gas, and carrier gas (high-purity nitrogen, $\geq 99.999 \%$ ) were 50 , 75 , and $100 \mathrm{kPa}$, respectively. The amount of sample was $1 \mu \mathrm{L}$. The injection port was operated in split mode $(30: 1)$. The data were analyzed using Tukey multiple comparison method with DPS software (version 6.55, Zhejiang University, China).

\section{RESULTS AND DISCUSSION}

\section{Effects of Single Factors on the Product Quality of Goat Milk Yogurt}

Amount of Sugar Added. Table 1 shows the effects of the amount of sugar added on the product quality of goat milk yogurt. The amounts of sugar added were $5,6,7,8,9$, and $10 \%$. The inoculation amount was $4 \%$. The ratio of 3 lactic acid bacteria - L. delbrueckii ssp. bulgaricus, S. thermophilus, and Lactobacillus rhamnosus GG - was 1:1:2 because in our preliminary experiments this ratio had demonstrated good product quality in yogurt. The fermentation temperature was $42^{\circ} \mathrm{C}$ and ripening time was $16 \mathrm{~h}$. The product quality of goat milk yogurt was evaluated by the titratable acidity, water-retaining capability, sensory score, and texture properties.

Adding sugar into the goat milk yogurt not only augments DM content but also promotes yogurt solidification, which then makes yogurt taste sour and sweet. As shown in Table 1, the sensory quality and texture quality were good when amounts of sugar added were 6 , 7,8 , or $9 \%$. If the amount of sugar added was too high the yogurt would taste sour, and if the amount of sugar added was too low the yogurt would taste too sweet. The values of titratable acidity and sensory score were the best and water-retaining capability, firmness, cohesiveness, and index of viscosity were good when the amount of sugar added was $7 \%$. Therefore, $6,7,8$, and $9 \%$ were chosen as the amounts of added sugar in the orthogonal experiment.

Inoculation Amount. Effects of inoculation amount on the product quality of goat milk yogurt were shown in Table 2. The amounts of inoculation were 2, 3, 4, 5, 6 , and $7 \%$. The amount of sugar added was $8 \%$. The ratio of the 3 lactic acid bacteria-L. delbrueckii ssp. bulgaricus, S. thermophilus, and L. rhamnosus GGwas 1:1:2. The fermentation temperature was $42^{\circ} \mathrm{C}$

Table 1. Effects of the amount of sugar added on the product quality of goat milk yogurt

\begin{tabular}{lccccc}
\hline $\begin{array}{l}\text { Sugar added } \\
(\%)\end{array}$ & $\begin{array}{c}\text { Titratable } \\
\text { acidity }\left({ }^{\circ} \mathrm{T}\right)\end{array}$ & $\begin{array}{c}\text { Water-retaining } \\
\text { capability }(\%)\end{array}$ & $\begin{array}{c}\text { Firmness } \\
(\mathrm{g})\end{array}$ & $\begin{array}{c}\text { Cohesiveness } \\
(\mathrm{g})\end{array}$ & $\begin{array}{c}\text { Index of } \\
\text { viscosity }(\mathrm{g} \cdot \mathrm{s})\end{array}$ \\
\hline 5 & 90 & 24.91 & 37.195 & 16.784 & 32.723 \\
6 & 95 & 26.29 & 37.262 & 17.156 & 37.570 \\
7 & 101 & 28.35 & 38.024 & 17.257 & 33.993 \\
8 & 89 & 27.13 & 42.182 & 20.163 & 36.934 \\
9 & 85 & 26.03 & 39.797 & 17.294 & 85 \\
10 & 80 & 24.91 & 38.676 & 17.066 & 92 \\
\hline
\end{tabular}


JIA ET AL.

Table 2. Effects of inoculation amount on the product quality of goat milk yogurt

\begin{tabular}{lccccc}
\hline $\begin{array}{l}\text { Inoculation } \\
\text { amount }(\%)\end{array}$ & $\begin{array}{c}\text { Titratable } \\
\text { acidity }\left({ }^{\circ} \mathrm{T}\right)\end{array}$ & $\begin{array}{c}\text { Water-retaining } \\
\text { capability }(\%)\end{array}$ & $\begin{array}{c}\text { Firmness } \\
(\mathrm{g})\end{array}$ & $\begin{array}{c}\text { Cohesiveness } \\
(\mathrm{g})\end{array}$ & $\begin{array}{c}\text { Index of } \\
\text { viscosity }(\mathrm{g} \cdot \mathrm{s})\end{array}$ \\
\hline 2 & 80 & 26.33 & 50.845 & 23.505 & 48.029 \\
3 & 97 & 30.04 & 53.995 & 24.656 & 61.786 \\
4 & 95 & 28.60 & 52.229 & 24.465 & 58.968 \\
5 & 93 & 27.30 & 44.809 & 19.534 & 37.086 \\
6 & 92 & 26.50 & 41.018 & 17.656 & 89 \\
7 & 88 & 25.62 & 39.413 & 16.341 & 39.250 \\
\hline
\end{tabular}

and ripening time was $16 \mathrm{~h}$. The product quality of goat milk yogurt was then evaluated by the titratable acidity, water-retaining capability, sensory score, and texture properties.

As shown in Table 2, the value of titratable acidity was the lowest. Sensory score and texture quality were very low when the inoculation amount was $2 \%$. When the inoculation amount was $3 \%$, the value of titratable acidity was the best. Sensory score and texture quality were also good. Therefore, the inoculation amounts of $2,3,4$, and $5 \%$ were chosen in the orthogonal experiment.

Ratio of Strains. Effects of the ratio of strains on the product quality of goat milk yogurt were shown in Table 3. The ratios of the 3 lactic acid bacteria$L$. delbrueckii ssp. bulgaricus, S. thermophilus, and $L$. rhamnosus GG-were 2:2:1, 1:1:1, 1:1:2, 1:1:3, 1:1:4, and $1: 1: 5$. The amount of sugar added was $8 \%$, the inoculation amount was $4 \%$. The fermentation temperature was $42^{\circ} \mathrm{C}$ and ripening time was $16 \mathrm{~h}$. The product quality of goat milk yogurt was then evaluated by the titratable acidity, water-retaining capability, sensory score, and texture properties.

As shown in Table 3, the values of titratable acidity, water-retaining capability, sensory quality, and texture quality were good when the ratio of the 3 lactic acid bacteria was 1:1:4. The values of titratable acidity, water-retaining capability, and index of viscosity clearly decreased when the proportion of L. rhamnosus GG was increased. Protein gel would be dehydrated when the value of titratable acidity was too high. As a result, it lowered the water-retaining capability and made whey dissolve out of yogurt; thus, the index of viscosity was lessoned. The quality of goat milk yogurt would be improved when L. rhamnosus GG was added within proper proportion. Therefore, the ratios of the 3 lactic acid bacteria of 1:1:1, 1:1:2, 1:1:3, and 1:1:4 were chosen in the orthogonal experiment.

Fermentation Temperature. Effects of fermentation temperature on the product quality of goat milk yogurt are shown in Table 4 . The fermentation temperatures were $36,38,40,42,44$, and $46^{\circ} \mathrm{C}$. The amount of sugar added was $8 \%$. The inoculation amount was $4 \%$.
The ratio of the 3 lactic acid bacteria was 1:1:2 and ripening time was $16 \mathrm{~h}$. The product quality of goat milk yogurt was then be evaluated by the titratable acidity, water-retaining capability, sensory score, and texture properties.

As shown in Table 4, the sensory quality was the best when the fermentation temperature was $38^{\circ} \mathrm{C}$. Lactic acid bacteria grew slowly when the fermentation temperature was $36^{\circ} \mathrm{C}$, which lengthened the curd time; thus, the titratable acidity, sensory quality, and texture quality were not very good. When the fermentation temperature was $46^{\circ} \mathrm{C}$, such a high temperature restrained lactic acid bacteria growth. As a result, the water-retaining capability, sensory quality, and texture quality were not very good. Therefore the fermentation temperatures of $36,38,40$, and $42^{\circ} \mathrm{C}$ were chosen in the orthogonal experiment.

\section{Optimization of Goat Milk Yogurt Fermentation}

To determine the optimum fermentation process, amount of sugar added, inoculation amount, ratio of strains, and fermentation temperature were selected with titratable acidity, water-retaining capability, and sensory score as index by $\mathrm{L}_{16}\left(4^{4}\right)$ orthogonal experiment. Results of the orthogonal experiment and ANOVA are shown in Tables 5 and 6 .

A synthetic weighting method was used to determine the optimum fermentation process. It is hard to curdle yogurt if only L. rhamnosus GG is used as a starter. When L. delbrueckii ssp. bulgaricus, S. thermophilus, and L. rhamnosus GG were used as a starter in the fermentation process, curd time would be shortened, water-retaining capability and sensory quality would be improved, but titratable acidity would not have been affected. Therefore, water-retaining capability weighted value was $40 \%$, sensory score weighted value was $40 \%$, and the titratable acidity weighted value was $20 \%$.

The range $(\mathrm{R})$ value from Table 5 showed that factor B (inoculation amount) had a great influence on the product quality of goat milk yogurt compared with factors C (ratio of strains), A (amount of sugar added), and $\mathrm{D}$ (fermentation temperature), and the optimum 
Table 3. Effects of the ratio of strains (Lactobacillus delbrueckii ssp. bulgaricus to Streptococcus thermophilus to Lactobacillus rhamnosus GG) on the product quality of goat milk yogurt

\begin{tabular}{|c|c|c|c|c|c|c|}
\hline Ratio & $\begin{array}{c}\text { Titratable } \\
\text { acidity }\left({ }^{\circ} \mathrm{T}\right)\end{array}$ & $\begin{array}{l}\text { Water-retaining } \\
\text { capability }(\%)\end{array}$ & $\begin{array}{l}\text { Firmness } \\
(\mathrm{g})\end{array}$ & $\begin{array}{c}\text { Cohesiveness } \\
(\mathrm{g})\end{array}$ & $\begin{array}{c}\text { Index of } \\
\text { viscosity }(\mathrm{g} \cdot \mathrm{s})\end{array}$ & $\begin{array}{c}\text { Sensory } \\
\text { score }\end{array}$ \\
\hline $2: 2: 1$ & 80 & 26.63 & 41.532 & 18.477 & 34.218 & 78 \\
\hline $1: 1: 1$ & 85 & 26.99 & 43.946 & 18.994 & 37.444 & 81 \\
\hline $1: 1: 2$ & 88 & 26.78 & 44.790 & 19.470 & 38.373 & 86 \\
\hline $1: 1: 3$ & 90 & 27.21 & 46.500 & 19.800 & 40.265 & 89 \\
\hline $1: 1: 4$ & 92 & 28.03 & 49.304 & 21.225 & 42.398 & 90 \\
\hline $1: 1: 5$ & 86 & 27.85 & 40.887 & 17.738 & 33.294 & 84 \\
\hline
\end{tabular}

Table 4. Effects of fermentation temperature on the product quality of goat milk yogurt

\begin{tabular}{|c|c|c|c|c|c|c|}
\hline $\begin{array}{l}\text { Fermentation } \\
\text { temperature }\left({ }^{\circ} \mathrm{C}\right)\end{array}$ & $\begin{array}{c}\text { Titratable } \\
\text { acidity }\left({ }^{\circ} \mathrm{T}\right)\end{array}$ & $\begin{array}{l}\text { Water-retaining } \\
\text { capability }(\%)\end{array}$ & $\begin{array}{l}\text { Firmness } \\
(\mathrm{g})\end{array}$ & $\begin{array}{c}\text { Cohesiveness } \\
\text { (g) }\end{array}$ & $\begin{array}{c}\text { Index of } \\
\text { viscosity }(\mathrm{g} \cdot \mathrm{s})\end{array}$ & $\begin{array}{l}\text { Sensory } \\
\text { score }\end{array}$ \\
\hline 36 & 74 & 21.72 & 32.934 & 17.806 & 26.111 & 77 \\
\hline 38 & 86 & 25.80 & 41.127 & 21.101 & 35.686 & 94 \\
\hline 42 & 92 & 23.40 & 38.019 & 20.055 & 44.925 & 85 \\
\hline 44 & 94 & 22.46 & 36.324 & 18.781 & 41.483 & 83 \\
\hline 46 & 90 & 21.74 & 35.169 & 18.826 & 40.559 & 82 \\
\hline
\end{tabular}

Table 5. Results and analysis of orthogonal experiments

\begin{tabular}{|c|c|c|c|c|c|c|c|c|}
\hline $\begin{array}{l}\text { Test } \\
\text { number }\end{array}$ & \multicolumn{4}{|c|}{ Factor $^{2}$} & $\begin{array}{c}\text { Titratable } \\
\text { acidity }\left({ }^{\circ} \mathrm{T}\right)\end{array}$ & $\begin{array}{l}\text { Water-retaining } \\
\text { capability }(\%)\end{array}$ & $\begin{array}{l}\text { Sensory } \\
\text { score }\end{array}$ & Overall \\
\hline 3 & 1 & $3(4 \%)$ & $3(1: 1: 3)$ & $3\left(40^{\circ} \mathrm{C}\right)$ & 85 & 29.56 & 70 & 80.95 \\
\hline 4 & 1 & $4(5 \%)$ & $4(1: 1: 4)$ & $4\left(42^{\circ} \mathrm{C}\right)$ & 90 & 34.08 & 94 & 96.14 \\
\hline 5 & $2(7 \%)$ & 1 & 2 & 3 & 94 & 28.05 & 85 & 86.25 \\
\hline 8 & 2 & 4 & 3 & 2 & 96 & 28.36 & 88 & 89.06 \\
\hline 9 & $3(8 \%)$ & 1 & 3 & 4 & 91 & 28.53 & 75 & 80.97 \\
\hline 10 & 3 & 2 & 4 & 3 & 101 & 34.02 & 90 & 95.15 \\
\hline 11 & 3 & 3 & 1 & 2 & 96 & 31.80 & 81 & 88.16 \\
\hline 12 & 3 & 4 & 2 & 1 & 107 & 29.80 & 80 & 92.22 \\
\hline 13 & $4(9 \%)$ & 1 & 4 & 2 & 103 & 27.69 & 73 & 80.71 \\
\hline 14 & 4 & 2 & 3 & 1 & 89 & 30.65 & 80 & 86.45 \\
\hline $\mathrm{K}_{4}$ & 84.4350 & 89.8450 & 90.6025 & 89.4575 & & & & \\
\hline $\mathrm{R}$ & 5.0200 & 10.6100 & 6.6325 & 3.3800 & & & & \\
\hline
\end{tabular}

${ }^{1} \mathrm{~K}_{1}, \mathrm{~K}_{2}, \mathrm{~K}_{3}$, and $\mathrm{K}_{4}=$ the sum of experimental results of levels, 1, 2, 3, and 4, respectively; $\mathrm{R}$ (range) $=\mathrm{K}_{\max }-\mathrm{K}_{\min }$.

${ }^{2} \mathrm{~A}=$ amount of sugar added; $\mathrm{B}=$ inoculation amount; $\mathrm{C}=$ ratio of strains; $\mathrm{D}=$ fermentation temperature.

Table 6. Variance analysis of orthogonal experiments

\begin{tabular}{lcccrc}
\hline $\begin{array}{l}\text { Sources of } \\
\text { variation }^{1}\end{array}$ & Sum of squares & df & Mean square & $F$-value & $P$-value \\
\hline A & 65.3359 & 3 & 21.7786 & 4.0385 & 0.1408 \\
B & 245.7984 & 3 & 81.9328 & 15.1931 & 0.0256 \\
C & 138.6697 & 3 & 46.2232 & 8.5713 & 0.0555 \\
D & 26.8928 & 3 & 8.9643 & 1.6623 & 0.3433 \\
Error $^{2}$ & 16.1783 & 3 & 5.3928 & & \\
\hline
\end{tabular}

${ }^{1} \mathrm{~A}=$ amount of sugar added; $\mathrm{B}=$ inoculation amount; $\mathrm{C}=$ ratio of strains; $\mathrm{D}=$ fermentation temperature.

${ }^{2}$ Random error. 
Table 7. Effects of fermentation with Lactobacillus rhamnosus GG on short-chain fatty acids of goat milk yogurt

\begin{tabular}{|c|c|c|c|c|c|}
\hline Item $^{1}$ & $\mathrm{C} 4$ & $\mathrm{C} 6$ & $\mathrm{C} 8$ & $\mathrm{C} 10$ & $\Sigma(\mathrm{C} 4 \sim \mathrm{C} 10)$ \\
\hline $\mathrm{E}$ & $0.71 \pm 0.004^{\mathrm{a}}$ & $1.44 \pm 0.03^{\mathrm{a}}$ & $1.94 \pm 0.03^{\mathrm{a}}$ & $7.27 \pm 0.02^{\mathrm{a}}$ & $11.36 \pm 0.03^{\mathrm{a}}$ \\
\hline $\mathrm{F}$ & $0.75 \pm 0.002^{\mathrm{b}}$ & $1.51 \pm 0.009^{\mathrm{a}}$ & $2.04 \pm 0.04^{\mathrm{b}}$ & $7.44 \pm 0.06^{\mathrm{a}}$ & $11.74 \pm 0.08^{b}$ \\
\hline G & $0.00 \pm 0.00^{\mathrm{b}}$ & $1.84 \pm 0.004^{\mathrm{c}}$ & $0.00 \pm 0.00^{\mathrm{b}}$ & $4.77 \pm 0.04^{\mathrm{c}}$ & $0.52 \pm 0.02$ \\
\hline
\end{tabular}

${ }^{\mathrm{a}-\mathrm{c}}$ Means within the same column without a common superscript are significantly different $(P<0.05)$.

${ }^{1} \mathrm{E}=$ raw goat milk; $\mathrm{F}=$ goat milk fermentation with Lactobacillus rhamnosus $\mathrm{GG} ; \mathrm{G}=$ goat milk fermentation with the optimum fermentation condition.

combination was $\mathrm{A}_{2} \mathrm{~B}_{2} \mathrm{C}_{2} \mathrm{D}_{4}$. The product quality of goat milk yogurt was the best when the amount of sugar added was $7 \%$, the inoculation amount was $3 \%$, the ratio of the 3 lactic acid bacteria was 1:1:3, and fermentation temperature was $42^{\circ} \mathrm{C}$. As shown in Table 6 , factor $\mathrm{B}$ had a significant $(P<0.05)$ effect on the result, whereas factor $\mathrm{A}, \mathrm{C}$, and $\mathrm{D}$ had no significant effect on it. This is probably due to the small difference levels between each factor or a large error of measurement.

\section{Analysis of Goat Milk Yogurt Fatty Acids}

The fatty acids of raw goat milk (marked as E), goat milk fermentation with L. rhamnosus GG (marked as $\mathrm{F}$ ), and goat milk fermentation with the optimum fermentation conditions (marked as G) were determined by a gas chromatograph.

As shown in Tables 7, 8, and 9, the content of short-chain and medium-chain fatty acids increased significantly $(P<0.05)$ and the content of long-chain fatty acids decreased in goat milk fermentation with $L$. rhamnosus GG compared with raw goat milk. This is likely due to short-chain and medium-chain fatty acids being in the sn-3 position of the triglyceride molecule and these fatty acids were hydrolyzed first by lipoprotein lipase in fermented goat milk, which increased the percentage of short-chain and medium-chain fatty acids and decreased that of long-chain fatty acids, which improved absorptivity and health function of goat milk. The content of short-chain and medium-chain fatty acids deceased significantly $(P<0.05)$ and the content of long-chain fatty acids increased in goat milk fermentation with the optimum fermentation conditions compared with raw goat milk. This is probably due to inhibited activity of the lipoprotein lipase when $L$. delbrueckii ssp. bulgaricus and S. thermophilus with $L$. rhamnosus GG were mixed as a starter culture. The content of short-chain and medium-chain fatty acids decreased so as to weaken the "goaty" smell of goat milk.

\section{CONCLUSIONS}

The optimum fermentation conditions were optimized through single-factor experiments and orthogonal experiments. The results show that high product quality of goat milk yogurt can be obtained when the amount of sugar added was $7 \%$, inoculation amount was $3 \%$, the ratio of the 3 lactic acid bacteria- $L$. delbrueckii ssp. bulgaricus, S. thermophilus, and L. rhamnosus GG-was 1:1:3, and the fermentation temperature was $42^{\circ} \mathrm{C}$. Through the demonstration test, the value of titratable acidity is $101^{\circ} \mathrm{T}$, the water-retaining capability is $39.89 \%$, the sensory score is 95 , and the viable count reaches $10^{8}$ to $10^{9} \mathrm{cfu} / \mathrm{mL}$ when the optimum fermentation conditions were used. The content of short-chain and medium-chain fatty acids decreased significantly $(P<0.05)$ and the smell of goat milk was weakened in goat milk fermentation with the optimum fermentation conditions compared with raw goat milk and goat milk fermentation with L. rhamnosus GG through the analysis of goat milk yogurt fatty acids by a gas chromatograph. The resulting goat milk yogurt features

Table 8. Effects of fermentation with Lactobacillus rhamnosus GG on medium-chain fatty acids of goat milk yogurt

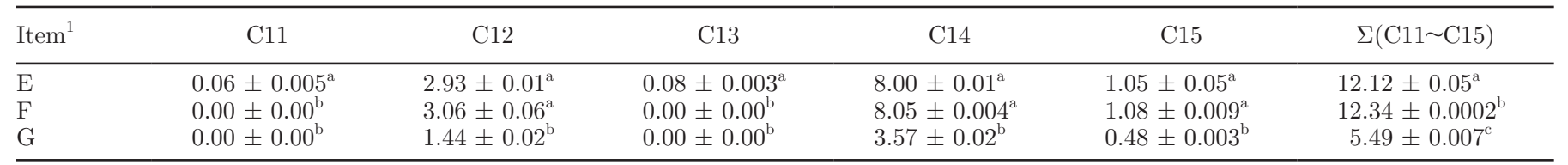

${ }^{\mathrm{a}-\mathrm{c}}$ Means within the same column without a common superscript are significantly different $(P<0.05)$.

${ }^{1} \mathrm{E}=$ raw goat milk; $\mathrm{F}=$ goat milk fermentation with Lactobacillus rhamnosus $\mathrm{GG} ; \mathrm{G}=$ goat milk fermentation with the optimum fermentation condition. 
Table 9. Effects of fermentation with Lactobacillus rhamnosus GG on long-chain fatty acids of goat milk yogurt

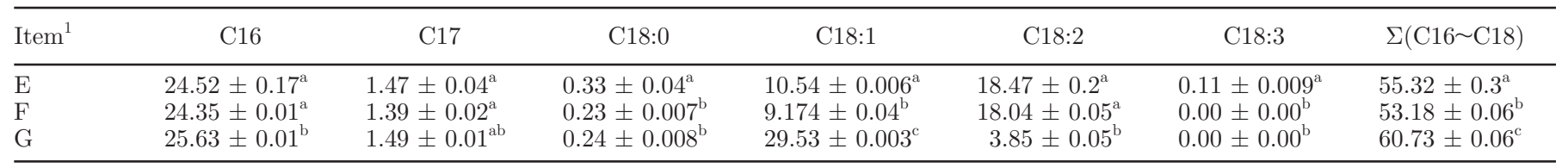

${ }^{\mathrm{a}-c}$ Means within the same column without a common superscript are significantly different $(P<0.05)$.

${ }^{1} \mathrm{E}=$ raw goat milk; $\mathrm{F}$ = goat milk fermentation with Lactobacillus rhamnosus $\mathrm{GG}$; $\mathrm{G}=$ goat milk fermentation with the optimum fermentation condition.

weak curds, fine and smooth texture, rich flavor, and pure yogurt taste.

\section{ACKNOWLEDGMENTS}

The authors gratefully acknowledge the financial support provided by the Natural Science Foundation of China (grant no. K332020916) and the Shaanxi Program for Science and Technology Development (Shaanxi Province, China; grant no. 2013k13-04-10). We also thank the technicians at College of Food Science and Engineering, Northwest A\&F University, China, for all their assistance during the trial.

\section{REFERENCES}

Alférez, M. J. M., M. Barrionuevo, I. Lopez-Aliaga, M. R. SanzSampelayo, F. Lisbona, J. C. Robles, and M. S. Campos. 2001. Digestive utilization of goat and cow milk fat in malabsorption syndrome. J. Dairy Res. 68:451-461.

Barber, M. C., R. A. Clegg, M. T. Travers, and R. G. Vernon. 1997. Lipid metabolism in the lactating mammary gland. Biochim. Biophys. Acta 1347:101-126.

Barrionuevo, M., M. J. M. Alferez, I. Lopez-Aliaga, M. R. Sanz-Sampelayo, and M. S. Campos. 2002. Beneficial effect of goat milk on nutritive utilization of iron and copper in malabsorption syndrome. J. Dairy Sci. 85:657-664.

Chilliard, Y., A. Ferlay, R. Mansbridge, and M. Doreau. 2000. Ruminant milk fat plasticity: Nutritional control of saturated, polyunsaturated, trans, and conjugated fatty acids. Ann. Zootech. 49:181-205.

Chilliard, Y., A. Ferlay, J. Rouel, and G. Lamberet. 2003. A review of nutritional and physiological factors affecting goat's milk lipid synthesis and lipolysis. J. Dairy Sci. 86:1751-1770.

Donkor, O. N., S. L. I. Nilmini, P. Stolic, T. Vasiljevic, and N. P. Shah. 2007. Survival and activity of selected probiotic organisms in settype yogurt during cold storage. Int. Dairy J. 17:657-665.

Gilliland, S. E. 2003. Probiotics. Pages 4792-4798 in Encyclopedia of Food Science and Nutrition. Academic Press, Oxford, UK.

Goldin, B. R., S. L. Gorbach, M. Saxelin, S. Barakat, L. Gualticri, and S. Salminen. 1992. Survival of Lactobacillus species (strain GG) in human gastrointestinal tract. Dig. Dis. Sci. 37:121-128.

Haenlein, G. F. W. 2001. Past, present and future perspectives of small ruminant dairy research. J. Dairy Sci. 84:2097-2115.

Haenlein, G. F. W. 2004. Goat milk in human nutrition. Small Rumin. Res. 51:155-163.

Hassan, A. N., J. F. Frank, K. A. Selunidt, and S. I. Shalabi. 1996. Textural properties of yogurt made with encapsulated nonropy lactic cultures. J. Dairy Sci. 79:2098-2103.
Hekmat, S., and G. Reid. 2006. Sensory properties of probiotic yogurt is comparable to standard yogurt. Nutr. Res. 26:163-166.

ISO. 2003. ISO 4121. Sensory analysis - Guidelines for the use of quantitative response scales. International Organization for Standardization, Geneva, Switzerland.

ISO. 2012. ISO 8586. Sensory analysis - General guidelines for the selection, training and monitoring of selected assessors and expert sensory assessors. International Organization for Standardization, Geneva, Switzerland.

Lin, F. M., C. H. Chiu, and T. M. Pan. 2004. Fermentation of a milksoymilk and Lycium chinense Mille mixture using a new isolate of Lactobacillus paracasei ssp. paracasei NTU101 and Bifidobacterium longum. J. Ind. Microbiol. Biotechnol. 31:559-564.

Linares, D., P. Michaud, A. M. Delort, M. Traikia, and J. Warrand. 2011. Catabolism of L-ascorbate by Lactobacillus rhamnosus GG. J. Agric. Food Chem. 59:4140-4147.

Lourens-Hattingh, A., and B. C. Viljoen. 2001. Yogurt as probiotic carrier food. Int. Dairy J. 11:1-17.

Merin, U. 2000. Influence of breed and husbandry on viscosity of Israeli goat milk yogurt. Small Rumin. Res. 35:175-179.

Millar, M. R., C. Bacon, S. L. Smith, V. Walker, and M. A. Hall. 1993. Enteral feeding of premature infants with Lactobacillus GG. Arch. Dis. Child. 69:483-487.

Park, Y. W. 1994. Hypo-allergenic and therapeutic significance of goat milk. Small Rumin. Res. 14:151-159.

Saxelin, M., M. Aokas, and S. Salminen. 1993. Dose response on the faecal colonization of Lactobacillus strain GG administered in two different formulations. Microb. Ecol. Health Dis. 6:119-122.

Senaka Ranadheera, C., C. A. Evans, M. C. Adams, and S. K. Baines. 2013. Production of probiotic ice cream from goat's milk and effect of packaging materials on product quality. Small Rumin. Res. 112:174-180.

Settachaimongkon, S., M. J. R. Nout, E. C. Antunes Fernandes, T. C. M. van Hooijdonk, M. H. Zwietering, E. J. Smid, and H. J. F. van Valenberg. 2014. The impact of selected strains of probiotic bacteria on metabolite formation in set yoghurt. Int. Dairy J. 38:1-10.

Slacacac, V., R. Bozanic, J. Hardi, J. R. Szabo, M. Lucan, and V. Krstanovic. 2010. Nutritional and therapeutic value of fermented caprine milk. Int. J. Dairy Technol. 63:171-189.

Soryal, K. A., S. S. Zeng, and B. R. Min. 2003. Fatty acid profiles of goat's milk and Domiati cheese as affected by pasture feeding and stage of lactation. J. Food Lipids 10:219-236.

Spuergin, P., M. Walter, E. Schiltz, K. Deichmann, J. Forster, and H. Mueller. 1997. Allergenicity of alpha-caseins from cow, sheep, and goat. Allergy 52:293-298.

Yang, C. J., W. Ding, L. J. Ma, and R. Jia. 2015. Discrimination and characterization of different intensities of goaty flavor in goat milk by means of an electronic nose. J. Dairy Sci. 98:55-67.

Zhao, L., S. Zhang, H. Uluko, L. Liu, J. Lu, H. Xue, F. Kong, and J. Lv. 2014. Effect of ultrasound pretreatment on rennet-induced coagulation properties of goat's milk. Food Chem. 165:167-174. 